\title{
Connotation and Implementation of Ideological and Political Education in Foreign Language Teaching
}

\author{
Bianqi Sun \\ School of Basic Education, Beijing Institute of Graphic Communication, Beijing, 102600, China \\ Corresponding author.Email: sunbianqi@bigc.edu.cn

\begin{abstract}
"Morality cultivation" is the fundamental task of higher education, and curriculum-based ideological and political education is a strategic measure to implement the fundamental task of "morality cultivation". The course with ideological and political elements is to put the value guidance in the teaching of knowledge and the cultivation of ability. This paper analyses the connotation of curriculum ideology and politics, analyses the problems existing in current teaching materials and the teachers' professional qualities and abilities required in the College English Teaching Guidelines, and points out the new goals, new tasks, new paths and new ideas in the new era, as well as how to implement curriculum ideology and politics into College English teaching.
\end{abstract}

Keywords: Curriculum-based ideological and political education, foreign language teaching, morality cultivation, student-centeredness, College English Teaching Guidelines

\section{INTRODUCTION}

Nowadays, there are some new development trends in education in the world, one of which is the transformation from ability-oriented to value-oriented. This value orientation is to educate students how to treat themselves, others, society, country and the world. Although different nationalities have different understandings of values, and the values advocated by various countries are also different, the consensus of regarding values education as the primary function of education is becoming more and more consistent.

Since the 18th CPC National Congress, general secretary Xi Jinping has attached great importance to the important position and role of morality cultivation in our education, and took the moral education as the fundamental task of education. At the same time, we emphasized repeatedly the important role of ideological and political education in the implementation of higher education. In August 2019, the General Office of the CPC Central Committee and the general office of the State Council issued several opinions on deepening the reform and innovation of school courses with ideological and political elements in the new era, emphasizing the need to deeply explore the ideological and political education resources contained in professional courses of various disciplines, and solve the problem of mutual cooperation and interaction between various courses and ideological and political courses. In 2020, the Ministry of Education issued the guidelines for curriculum-based ideological and political construction in colleges and universities. As an important measure to implement morality and cultivate talents, moral education requires that each course should play a role in educating people and cultivate socialist builders and successors with all-round development of morality, intelligence, health, aesthetics and work skills[1][2].

\section{THE CONNOTATION OF IDEOLOGICAL AND POLITICAL COURSES}

Curriculum ideological and political education is to put ideological and political education through the talent training system, giving full play to the educational role of each course, and implementing the fundamental task of morality cultivation. As an important measure to implement morality cultivation, curriculum-based ideological and political education is to integrate value shaping, knowledge teaching and ability training, and integrate values into knowledge teaching and ability training in teaching. This is to make all kinds of courses and ideological and political theory courses go in the same direction, and effectively integrate explicit 
education and implicit education, and give full play to the ideological and political education function carried by the curriculum, and build a pattern of full-time and all-round education. As an important part of China's education, how to implement curriculum-based ideology and politics in foreign language education is worthy of our serious thinking and profound research. In order to implement curriculum-based ideology and politics in foreign language education, we must integrate the socialist core values into the teaching of foreign language knowledge and the development of abilities, and help students shape a correct world outlook, outlook on life and values. Whether the ideological and political implementation of foreign language education curriculum is good or not mainly depends on foreign language teachers, curriculum construction, classroom teaching, foreign language teaching materials and teaching evaluation etc.

\section{THE NECESSITY OF CHANGING IDEAS}

Morality cultivation and curriculum-based ideological and political education put forward new requirements and goals for College English teaching. Curriculum-based ideological and political education itself is a new requirement and goal for talent training and curriculum teaching. Specifically, talent training should change from knowledge teaching, ability training and quality improvement to a higher goal of value cultivation of well-round talents, with character shaping, knowledge teaching, ability training and quality improvement, organically combining the four, and solidly establishing the Holistic Education objectives. We should further highlight the improvement of ability and quality, and put more emphasis on critical and inclusive thinking and the ability to solve comprehensive problems, and put more emphasis on global cooperative thinking and cross-border leadership. Furthermore, we need to put more emphasis on initiative and initiative spirit and flexible adaptability and put more emphasis on curiosity, imagination and information evaluation ability, and put more emphasis on the shaping of ideological morality and personality charm[3].

\section{COLLEGE ENGLISH TEACHING GUIDELINES AND NEW REQUIREMENTS}

The new College English Teaching Guidelines puts forward new requirements and objectives for the nature of the curriculum, curriculum objectives, curriculum resources, teaching methods and teacher development, and clearly points out that the nature of the College English curriculum is to cultivate students' ability to understand and interpret Chinese culture and serve the external dissemination of Chinese culture. Socialist core values should be organically integrated into College
English teaching content; the curriculum needs to fully integrate its ideological and emotional resources in all links such as curriculum construction, textbook compilation and teaching implementation, enriching its humanistic connotation and realizing the organic unity of instrumentality and humanism. College English teaching should be actively integrated into the school curriculum-based ideological and political teaching system, so as to play an important role in the implementation of the fundamental task of morality cultivation in Colleges and universities.

The guide points out the new teaching objectives of College English are to cultivate students' English application ability, enhance cross-cultural communication awareness and communication ability, develop autonomous learning ability, improve comprehensive cultural literacy, and cultivate humanistic spirit, so that students can use English properly and effectively in their study, life and future work, and meet the needs of national, social, and personal development, establishing a correct world outlook, outlook on life and values.

The guideline requires that the first-class curriculum construction must enrich the curriculum content, help students enhance their innovative spirit, entrepreneurial awareness, family and country feelings and the ability to integrate China and foreign countries, improve their ideological and moral cultivation, humanistic quality, scientific spirit, constitutional and legal awareness, national security awareness and cognitive ability, integrating the curriculum ideological and political ideas and content into the curriculum.

The guide also points out that the construction of first-class courses and teaching materials is the core content. It is an important carrier for spreading new knowledge, new ideas and new ideas, the main carrier of teaching content and the basic guarantee for achieving teaching objectives. The guiding ideology for the compilation of College English textbooks should reflect the new era, new requirements and the basic requirements of the party and the state for education. We should consciously strengthen cultural self-confidence, adhere to the subjectivity of Chinese culture and stick to Chinese culture. College language education should consciously integrate into the socialist core values and excellent Chinese traditional culture, and guide students to establish a correct world outlook, outlook on life and values. The selection of teaching materials should be based on morality cultivation, and broaden their horizons to practice the fundamental task of fostering virtue and morality in students. All-round talents with international vision should be able to absorb the excellent achievements of human civilization and cultivate forward-looking thinking.

The new objectives, new requirements and new ideas in the guideline urgently need to change the 
concept of College English Teaching in the new era, taking the reform of teaching content as the most practical starting point. To achieve good results, we need to promote the construction of teachers and curriculum, and fully implement the fundamental task of morality cultivation.

\section{THE CONTENT OF EXISTING TEACHING MATERIALS IS DIFFICULT TO MEET THE NEW NEEDS}

The existing teaching materials, such as the comprehensive college English Course published by FLTRP, FLTRP and higher education society, are difficult to fully meet the new requirements of moral education.

Teaching requirements and objectives are mainly reflected in the following aspects.

First, no textbook is clearly put forward, and its compilation purpose and teaching material content serve to establish morality and cultivate people and serve the curriculum-based ideological and political education.

Second, the proportion of Chinese culture and science and technology reflected in various textbooks is seriously insufficient, and some textbooks are basically rare, which is of great significance to the cultivation of science

It is very disadvantageous for students to tell Chinese stories, spread Chinese culture and establish Chinese cultural self-confidence.

Third, we do not pay enough attention to the cultivation and promotion of moral sentiment, which is reflected in two aspects: first, the display is not enough and there is no clear teaching material

The second is that the content is scattered and the content of each unit is different

The practice design is difficult to see the organic integration of Ideological and political elements into the learning of language knowledge.

Fourth, the discreteness of teaching activities, language learning content and practice design of each unit is prominent, and the goal of education is not formed

In the organic whole of logic, it is difficult to form the joint force of language knowledge teaching, language ability training, quality improvement and value shaping.

Fifth, the disconnection phenomenon is serious, although some textbooks will put forward the idea of cultivating students' qualities such as "integrity" in some units

The goal, but either it is not implemented, or it is label processing. The phenomenon of "two skins" is more serious.[4]

\section{TEACHERS' IDEALS, BELIEFS, EDUCATIONAL CONSCIOUSNESS AND ABILITY}

According to the opinions of the CPC Central Committee and the State Council on comprehensively deepening the construction and reform of teachers in the new era, We should strengthen our ideals and beliefs education, and further study and understand Xi Jinping's new socialist ideology with Chinese characteristics, and guide teachers to establish correct historical outlook, national outlook, cultural outlook, and strengthen China's socialist road self-confidence, theoretical self-confidence, institutional self-confidence and cultural self-confidence. China should guide teachers to accurately understand and grasp the profound connotation of socialist core values. Strengthen the ability of value judgment, selection and shaping, and take the lead in practicing the socialist core values " It can be said that if a teacher does not have correct and firm ideals and beliefs, it is difficult to practice these requirements in his daily words and deeds, it is conceivable that he will be difficult to realize the important role of curriculum ideological politics in teaching, let alone effectively implement curriculum ideological politics, so as to achieve the effect of moistening things and educating people silently.

Secondly, linguistic teachers must have the awareness of educating people. Without the awareness of educating people, they are likely to confine themselves to the "personal stage" of reading according to the book and stay away from the essence of education; because the essence of education is educating people, all teachers' work should actively focus on the all-round development of students. Teachers must "We must adhere to the unity of teaching and educating people, the unity of speech and practice, the unity of asking questions and paying attention to society, and the unity of academic freedom and academic norms". We must "establish ourselves, learn and teach with morality" [4] When teaching the basic concepts, viewpoints and theories of linguistics, we must always remember the mission of educating people, strengthen our awareness of educating people, and identify the perspective of educating people. As in May 4, 2014, general secretary $\mathrm{Xi}$ Jinping pointed out at the symposium with teachers and students of Peking University: "Teachers should always bear in mind the mission of teaching and educating people, be willing to be a ladder and a paving stone, guide students' hearts with personality charm and open the door of students' wisdom with academic attainments". Teachers should not only be good teachers of "Four Haves" but also be "four guides"; in linguistics teaching, they should not 
only impart professional knowledge, but also achieve the effect of moistening things silently[5].

Thirdly, linguistic teachers should also improve their ability to educate people, and learn to be a teacher and behave in the world. Teachers' national feelings, moral sentiment, international vision, knowledge level, historical consciousness, personality charm, professional ability, teaching skills, teaching style, language art, academic charm, speech and behaviour are the embodiment of their teaching and educating ability. Therefore, teachers should set an example in all aspects and improve their comprehensive quality and teaching and educating ability, and use their superb teaching ability to implement curriculum thinking and politics, and implement the fundamental task of morality cultivation[6].

\section{CONCLUSION}

Foreign language teachers need to deeply understand the national education policy, constantly study the curriculum and teaching theory, and strive to improve their foreign language discipline literacy, so as to grasp the essence of foreign language curriculum ideology and politics and systematically improve their teaching design ability. Teachers continue to improve their teaching ideas, and optimize curriculum design to integrate their own discipline expertise and innovative achievements into classroom teaching, and effectively improve the quality of the curriculum, creating a "golden course" itself is to show students professionalism and professional attitude, which is an organic part of the course's ideological and political education.

The ideological and political teaching of foreign language curriculum should be organically integrated with the teaching of language knowledge and skills. Teachers should help students think critically through teaching design, realize the shaping of values in the process of systematically analysing and solving problems, and guide students to consciously practice correct values in the new context. In-depth teaching will help to improve the ideological and humanistic nature of foreign language teaching and deepen the reform of foreign language teaching connotation, improve teaching efficiency, and realize the goal of cultivating all-round developed socialist builders and successors.

\section{ACKNOWLEDGMENTS}

This research is supported by program of Postgraduate Discipline Construction of BIGC (21090121030); Program of Quality Improvement of BIGC (22150120015).

\section{REFERENCES}

[1] Xi Jinping. Speech on Ideological and Political Work in Colleges and Universities at the National Conference [OL] http://www.xinhuanet.com// politics/2016-12/08/c_ 1120082577.htm (visit Time: June 6, 2020)

[2] Ministry of education of the people's Republic of China, Comments on the Reform of Science Education and Teaching to Improve the Quality of Talent Training in an All-round Way [OL] http://www.moe.gov.cn/srcsite/A08/s7056/201910/ t20191011_402759.html (visit Time: June 6, 2020)

[3] Liu Zhengguang \& Yue Manman Resetting the Educational Philosophy and Restructuring Learning Content to Implement Morality Cultivation in Foreign Language Course Instruction[J]. Journal of Foreign Languages, 2020. 9 (5) :21-29

[4] Hong Gang, Reflections on the Development of Curriculum-Based Political and Virtuous Awareness in International Studies Universities[J]. Technology Enhanced Foreign Languages, 2020. 6: 23-26

[5] Wen Xu, How to Implement Ideological-Political Instruction in Linguistics Courses[J]. Foreign Languages in China, 2021.3 (2): 71-77

[6] Guidelines for Curriculum-based Ideological and Political Construction of in Colleges and Universities (2020), May 28, 2004 http://www.gov.cn/zhengce/zhengceku/2020-06/06 /content_5517606.htm. (Date of visit: November 30,2020 ) 